\title{
INTRAPULPAL TEMPERATURE VARIATION DURING BLEACHING WITH VARIOUS ACTIVATION MECHANISMS
}

\author{
Sílvia Masae de Araujo MICHIDA ${ }^{1}$, Sheila Pestana PASSOS ${ }^{1}$, Ângela Regina Kimie MARIMOTO ${ }^{2}$,
} Márcia Carneiro Valera GARAKIS ${ }^{3}$, Maria Amélia Máximo de ARAÚJO ${ }^{3}$

1- DDS, MSc, Graduate student, Department of Dental Materials and Prosthodontics, São Paulo State University, São José dos Campos, SP, Brazil.

2- DDS, MSc, Graduate student, Department of Restorative Dentistry, São Paulo State University, São José dos Campos, SP, Brazil.

3- DDS, MSc, PhD, Adjunct Professor, Department of Restorative Dentistry, São Paulo State University, São José dos Campos, SP, Brazil.

Corresponding address: Sílvia Masae de Araujo Michida - Rua Luis Jacinto \#88/704 - São José dos Campos, SP - Brasil - 12245-710 - Phone: +55-1297440899 - e-mail: silviamasae@yahoo.com

Received: August 22, 2008 - Modification: November 30, 2008 - Accepted: January 07, 2009

\begin{abstract}
$O$

bjectives: The aim of this study was to evaluate the intrapulpal temperature variation after bleaching treatment with $35 \%$ hydrogen peroxide using different sources of activation. Material and Methods: Twenty-four human teeth were sectioned in the mesiodistal direction providing 48 specimens, and were divided into 4 groups $(n=12)$ : (G1) Control - Bleaching gel without light activation, (G2) Bleaching gel + halogen light, (G3) Bleaching gel + LED, (G4) Bleaching gel + Nd:YAG Laser. The temperatures were recorded using a digital thermometer at 4 time points: before bleaching gel application, 1 min after bleaching gel application, during activation of the bleaching gel, and after the bleaching agent turned from a dark-red into a clear gel. Data were analyzed statistically by the Dunnet's test, ANOVA and Tukey's test $(\alpha=0.05)$. Results: The mean intrapulpal temperature values $\left({ }^{\circ} \mathrm{C}\right)$ in the groups were: G1: $0.617 \pm 0.41 ; \mathrm{G} 2: 1.800 \pm 0.68$; G3: $0.975 \pm 0.51$; and G4: $4.325 \pm 1.09$. The mean maximum temperature variation (MTV) values were: $1.5^{\circ} \mathrm{C}(\mathrm{G} 1), 2.9^{\circ} \mathrm{C}(\mathrm{G} 2), 1.7^{\circ} \mathrm{C}(\mathrm{G} 3)$ and $6.9^{\circ} \mathrm{C}(\mathrm{G} 4)$. When comparing the experimental groups to the control group, G3 was not statistically different from G1 (p>0.05), but G2 and G4 presented significantly higher $(p<0.05)$ intrapulpal temperatures and MTV. The three experimental groups differed significantly $(\mathrm{p}<0.05)$ from each other. Conclusions: The Nd:YAG laser was the activation method that presented the highest values of intrapulpal temperature variation when compared with LED and halogen light. The group activated by LED light presented the lowest values of temperature variation, which were similar to that of the control group.
\end{abstract}

Key words: Tooth bleaching. Temperature.

\section{INTRODUCTION}

The increasing cultural appeal of beauty has reached great proportions. Good appearance is synonymous with personal and professional success. Dentistry assumes an important role in this search for esthetics.

Tooth discoloration is becoming a greater concern as more emphasis is placed on esthetics. With the growing awareness of esthetic options, there is greater demand for solutions to such unsightly problems as food staining, fluorosis, and tetracycline staining. Bleaching is one of the corrective measures used to treat discolored teeth. Bleaching can be performed internally on nonvital teeth or externally on vital teeth. Hydrogen peroxide, sodium perborate, and carbamide peroxide are generally used for bleaching 21,26 . These materials are found effective for bleaching teeth, but side effects of bleaching procedures include changes in tooth structure $^{12,18}$, microleakage of restorations ${ }^{5}$, external root resorption, and pulpal irritation ${ }^{17,19}$.
Bleaching systems offer easy-to-use bleaching agents, essentially using highly concentrated hydrogen peroxide mixed with thickening agents or additional buffering agents, catalysts, or heat-enhancing colorants 9 . Over 100 years ago, dental bleaching appeared as a technique for enhancing esthetics ${ }^{6}$. Currently, patients constantly request this procedure to overcome some esthetic dissatisfaction related to the color of their teeth, since it provides satisfactory results when well indicated.

The most frequently used substances for bleaching vital teeth are $10 \%$ to $37 \%$ carbamide peroxide, and $1.5 \%$ to $38 \%$ hydrogen peroxide, with the more concentrated products reserved for professional use in the dental office ${ }^{16}$. Camargo, et al. $^{4}$ (2007), evaluated the penetration of $38 \%$ hydrogen peroxide into the pulp chamber in bovine and human teeth submitted to the office bleaching technique. The teeth were restored with composite resin, conventional glass ionomer cement and resin-modified glass ionomer cement. Those authors found that a higher amount of hydrogen peroxide 
penetrated into the pulp chamber in resin-modified glass ionomer cements in both the bovine and human groups. Greater bleaching agent penetration into the pulp chamber occurred in human teeth for any experimental situation. The penetration of hydrogen peroxide depends on the restorative material, with human teeth being more susceptible to penetration of the bleaching agent into the pulp chamber than bovine teeth.

In order to accelerate the dental bleaching process, activation sources may be used, such as halogen, laser or light-emitting diode (LED) light. However, these sources may present photothermal effects which, when associated with the chemical effect of the bleaching materials, may cause damage to the pulp tissues.

For Zach and Cohen ${ }^{25}$, a $3.3^{\circ} \mathrm{C}$ temperature increase resulted in reversible histological alterations, while an intrapulpal temperature rise of $5.6^{\circ} \mathrm{C}$ may cause irreversible thermal pulpal damage, including pulp necrosis in $15 \%$ of the cases.

Eldeniz, et al. ${ }^{7}$ assessed the in vitro intrapulpal temperature increase induced by $35 \%$ hydrogen peroxide when exposed to different sources of light activation: conventional halogen light, high intensity halogen light, LED and diode laser. Those authors found that the diode laser induced significantly higher temperature increases than any other activation unit, while LED produced the least temperature variation.

Since there are few studies addressing the temperature variations in teeth undergoing to bleaching, the purpose of the present study was to evaluate the temperature inside the pulp chamber of teeth subjected to bleaching treatment with $35 \%$ hydrogen peroxide, using different sources of activation (Nd:YAG laser, LED and halogen light).

\section{MATERIAL AND METHODS}

Twenty-four healthy human molars were used. The teeth were cleaned and had the roots embedded in chemically activated acrylic resin in a silicone mold. After resin polymerization and pumice rubber cup prophylaxis of the tooth crown, the teeth were bisected in a mesiodistal direction (LabCut 1010, Erios, São Paulo, SP, Brazil), producing a buccal and a lingual segment to facilitate access to the pulp chamber for measuring the temperature. The specimens were stored in saline at $37^{\circ} \mathrm{C}$ for $24 \mathrm{~h}$. The dental structure thickness was measured in the vestibular-lingual direction with the aid of a caliper to distribute the specimens in a paired mode by thickness. The specimens were distributed into 4 groups $(n=12)$ according to the activation mechanism used: Group 1 (control): bleaching gel without light activation; Group 2 (Halogen): bleaching gel + activation with halogen light (XL 3000; 3M/ESPE, St. Paul, MN, USA; $500 \mathrm{~mW} / \mathrm{cm}^{2}$ ); Group 3 (LED): bleaching gel + activation with LED (Three Light - $470 \mathrm{~nm}$, Cleanline Produtos Odontológicos, São Paulo, SP, Brazil); Group 4 (Nd:YAG): bleaching gel + activation with high intensity $\mathrm{Nd}$ :YAG non-contact laser scanning $-8 \mathrm{~Hz}, 600 \mathrm{~mJ}$ and
0.6 W (Pulse Master 600 IQ; American Dental Technologies, Inc. Corpus Christi, TX, USA).

Before the bleaching treatment, a thermal paste (Implastec; Votorantim Indústria Brasileira, São Paulo, SP, Brazil) was introduced in the pulp chamber, in order to improve thermal conductance. The tip of a digital thermometer (Termopar MT-507; Minipa, São Paulo, SP, Brazil) was then introduced to the pulpal chamber, as closely as possible to the external surface of the tooth.

The bleaching gel used was $35 \%$ hydrogen peroxide (Whiteness HP; FGM, Joinville, SC, Brazil), which was applied over the entire enamel area, according to the manufacturer's instructions, forming a 0.5-1.0-mm-thick layer and allowing the bleaching agent to remain undisturbed for $1 \mathrm{~min}$. Light application for was done for $20 \mathrm{~s}$, keeping a distance of $5 \mathrm{~mm}$ from the gel surface for all the light sources used. A metallic apparatus was built to keep this distance. Before and at the beginning of light activation, the color of the gel was dark-red and turned into clear after removal of the light source.

The temperature inside the pulp chamber was measured before the bleaching gel application $\left(\mathrm{T}_{0}\right), 1 \mathrm{~min}$ after bleaching gel application $\left(\mathrm{T}_{1}\right)$, during activation of the bleaching gel $\left(\mathrm{T}_{2}\right)$, and after the bleaching agent turned from a dark-red into a clear gel $\left(\mathrm{T}_{3}\right)$. In the control group, the temperatures were obtained in the same way as in the experimental groups, but without activation by a light source. The temperature data obtained were analyzed statistically (Mini-Tab 14.12, 2004) by Dunnett's, ANOVA and Tukey's tests. Significance level was set at $5 \%$ for all analyses.

The maximum temperature variation (MTV) observed in each specimen was calculated using the following equation: $\mathrm{MTV}=$ maximum value between $\left(\mathrm{T}_{1}, \mathrm{~T}_{2}, \mathrm{~T}_{3}\right)-$ value of $\mathrm{T}_{0}$.

\section{RESULTS}

The mean intrapulpal temperature values $\left({ }^{\circ} \mathrm{C}\right)$ in the groups were: G1: $0.617 \pm 0.41 ; \mathrm{G} 2: 1.800 \pm 0.68 ; \mathrm{G} 3: 0.975$ \pm 0.51 ; and G4: $4.325 \pm 1.09$ (Table 1). The mean MTV recorded in the groups was as follows: $1.5^{\circ} \mathrm{C}(\mathrm{G} 1), 2.9^{\circ} \mathrm{C}$ (G2), $1.7^{\circ} \mathrm{C}(\mathrm{G} 3)$ and $6.9^{\circ} \mathrm{C}(\mathrm{G} 4)$ (Figure 1). When comparing the experimental groups to the control group using the Dunnett's, the group whose specimens were

TABLE 1- Mean intrapulpal temperature values $\left({ }^{\circ} \mathrm{C}\right)$ in the groups

\begin{tabular}{lll}
\hline Groups & N & Mean (士SD) \\
\hline G1 & 12 & $0.617 \pm 0.41 \mathrm{~A}$ \\
G2 & 12 & $1.800 \pm 0.68 \mathrm{~B}$ \\
G3 & 12 & $0.975 \pm 0.51 \mathrm{~A}$ \\
G4 & 12 & $4.325 \pm 1.09 \mathrm{C}$ \\
\hline
\end{tabular}

Same letter indicate no statistically significant differences among the groups. 


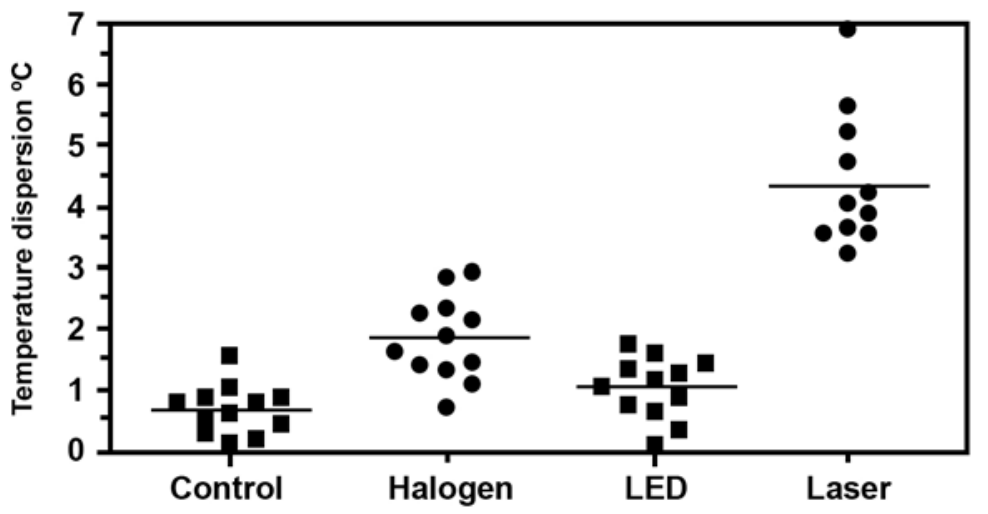

FIGURE 1- Temperature dispersion graph as a function on the groups

activated with the LED light (G3) was not statistically different from G1 ( $>0.05)$, but the groups activated with halogen light (G2) and Nd:YAG laser (G4) presented significantly higher $(\mathrm{p}<0.05)$ intrapulpal temperatures and MTV. The three experimental groups differed significantly from each other $(\mathrm{p}<0.05$; ANOVA and Tukey's test $)$.

\section{DISCUSSION}

The effectiveness of in-office vital bleaching agents has been extensively investigated. However, depending on the technique, bleaching agent concentration and the duration of use, this procedure may cause damage to the pulp tissue. Therefore, the intrapulpal temperature has been a reason of concern $^{23}$.

Zach and Cohen ${ }^{25}$ showed that intrapulpal temperature variations greater than $3.3^{\circ} \mathrm{C}$ resulted in the inicial reversible histologic alterations. Zezell, et al. ${ }^{27}$ found that, with an increase of $5.5^{\circ} \mathrm{C}$, odontoblast destruction begins in the pulp tissue.

In the present study, the mean temperature in the group activated with laser $\mathrm{Nd}$ :YAG $\left(4.325^{\circ} \mathrm{C}\right)$ was significantly higher than that in the control group $\left(0.617^{\circ} \mathrm{C}\right)$; the group activated with halogen light $\left(1.800^{\circ} \mathrm{C}\right)$ and the group activated with $\operatorname{LED}\left(0.975^{\circ} \mathrm{C}\right)$. Despite the lack of light application in the control group, a temperature increase of about $1^{\circ} \mathrm{C}$ was observed due to the exothermic reaction of the bleaching agent.

Furthermore, in the group activated with laser, some of the specimens presented temperatures up to $6.9^{\circ} \mathrm{C}$; an increase sufficient for tissue alterations, including pulpal necrosis. Nevertheless, there were no specimens in the other groups whose temperature values exceeded $3.0^{\circ} \mathrm{C}$. Vandewalle, et al. ${ }^{22}$ assessed the emission of heat from two different light sources and found that there was no significant difference between LED and halogen light, whereas Asmussen and Peutzfeldt ${ }^{1}$ found that halogen light induced a higher temperature than LED.

Some studies have shown the Nd:YAG laser ${ }^{13,15,24}$, with one of the concerns about using IT intraorally being its thermal effect, especially on dental pulp ${ }^{16}$. White, et al. ${ }^{23}$ used a Nd:YAG laser to check the temperature variation that occurs inside the pulp chamber. These authors concluded that intrapulpal temperature increased as the laser parameters increased (frequency, type of pulse) and diminished with greater dentin thickness. In the present study, care was taken to standardize the groups with homogeneous dentin thicknesses, as Sulieman, et al..$^{20}$ found that dentin thickness was a factor that must be considered in intrapulpal temperature variations. The greater the dentin thickness, the better the pulp protects against bleaching agents. Moreover, the defense system could reduce the damage of pulp tissue in relation to temperature increase; therefore, the results obtained in vitro can not correspond to in vivo results.

The aim of using light sources to help the bleaching procedure is to accelerate the decomposition of hydrogen peroxide, releasing oxidation radicals to break the dark colored molecules. However, the activation sources that generate heat in the dental structure also cause expansion of the liquids inside the dentinal tubules and pulp, which could lead to pulpal hyperemia with consequent postbleaching hypersensitivity ${ }^{8,10}$. In addition, the chemical effect of the oxidation radicals could contribute to greater aggression by the bleaching procedure to the pulp tissue ${ }^{3}$. Pulpal changes caused by bleaching agents have been investigated by several authors. Seale, et al. ${ }^{19}$ (1981) found that histological damage to dog teeth when using hydrogen peroxide alone or with heat is reversible after 60 days. They reported histological evidence of the disappearance of the odontoblastic layer under the treated area, with a dense inflammatory infiltrate and area of scalloped dentin. An intact pulpal blood flow could act as an efficient heat sink, with the pulpal circulation being able to dissipate some of the applied heat before pulpal cells are damaged ${ }^{8}$.

Another factor that could be associated with postbleaching hypersensitivity is dehydration of the bleached tooth, which would be more intense when the procedure is associated with heat ${ }^{11}$. Heat and light have been used empirically in attempt to catalyze hydrogen peroxide decomposition and speed tooth lightening. Furthermore, the natural dentinal fluid flow from the pulp and through the dental structure was not simulated and this flow could also impede the transfer of heat to the pulpal tissues. The present study demonstrates the potential for pulpal damage with the laser is higher than other procedures and, as such, needs to 
be used with caution.

The most suitable bleaching agents to use in association with the activation procedure are those with pigments. It is believed they allow greater light absorption by hydrogen peroxide, which results in less transmission of energy to the dental structure, and consequently lower values of temperature transmitted to the pulp tissue, and less postbleaching hypersensitivity. Nevertheless, further studies are required ${ }^{14}$ to confirm this possibility.

In the present study, the mechanisms of activation for bleaching procedures had a significant effect on the intrapulpal temperature values, which is in agreement with Baik, et al. ${ }^{2}$. The bleaching activation with LED promotes less temperature variation inside the pulp chamber. Thus, the method of activation by LED may be considered safe.

\section{CONCLUSIONS}

The results support the views that: 1. The bleaching procedure activated with $\mathrm{Nd}$ :YAG laser raises the temperature inside the pulp chamber to levels that could cause severe pulpal damage; 2 . Activation with LED was the method with the least temperature rise in the pulp chamber, therefore with the potential of causing less damage to the pulp tissue.

\section{REFERENCES}

1- Asmussen E, Peutzfeldt A. Temperature rise induced by some light emitting diode and quartz-tungsten-halogen curing units. Eur J Oral Sci. 2005;113:96-8.

2- Baik JW, Rueggeberg FA, Liewehr FR. Effect of light-enhanced bleaching on in vitro surface and intrapulpal temperature rise. $\mathrm{J}$ Esthet Restor Dent. 2001;13:370-8.

3- Benetti AR, Valera MC, Mancini MNG, Miranda CB, Balducci I. In vitro penetration of bleaching agents into the pulp chamber. Int Endod $\mathrm{J}$. 2004;37:120-4

4- Camargo SE, Valera MC, Camargo $\mathrm{CH}$, Gasparoto Mancini $\mathrm{MN}$, Menezes MM. Penetration of $38 \%$ hydrogen peroxide into the pulp chamber in bovine and human teeth submitted to office bleach technique. J Endod. 2007;33(9):1074-7.

5- Crim GA. Prerestorative bleaching: effect on microleakage of class V cavities. Quintessence Int. 1992;23:823-5.

6- Darnell DH, Moore WC. Vital tooth bleaching: the white and brite technique. Compend Contin Educ Dent. 1990;11:86-93.

7- Eldeniz AU, Usumez A, Usumez S, Ozturk N. Pulpal temperature rise during light-activated bleaching. J Biomed Mater Res B Appl Biomater. 2005;72B:254-9

8- Goodis HE, White JM, Andrews J, Watanabe LG. Measurement of temperature generated by visible-light-cure lamps in an in vitro model. Dent Mater. 1989;5:230-4.

9- Hein DK, Ploeger BJ, Hartup JK, Wagstaff RS, Palmer TM, Hansen LD. In-office vital tooth bleaching: what do lights add? Compend Contin Educ Dent. 2003;24:340-52.
10- Hannig M, Bott B. In vitro pulp chamber temperature rise during composite resin polymerization with various light-curing sources. Dent Mater. 1999;15:275-81.

11- Jones A, Diaz-Arnold A, Vargas M, Cobb D. Colorimetric assessment of laser and home bleaching techniques. J Esthet Dent. 1999;11:87-94.

12- Ledoux WR, Malloy RB, Hurst RVV, McInnes-Ledoux P, Weinberg R. Structural effects of bleaching on tetracycline stained vital rat teeth. J Prosthet Dent. 1985;54:55-9.

13- Lee MT, Bird PS, Walsh LJ. Photo-activated disinfection of the root canal: a new role for lasers in endodontics. Aust Endod J. 2004;30:93-8.

14- Luk K, Tam L, Hubert M. Effect of light energy on peroxide tooth bleaching. J Am Dent Assoc. 2004;135:194-201.

15- Mehl A, Kremers L, Salzmann K, Hickel R. 3D volume-ablation rate and thermal side effects with the Er:YAG and Nd:YAG laser. Dent Mater. 1997;13:246-51.

16- Miserendino L, Neiburger E, Pick R. Current status of laser in dentistry. Ill Dent J. 1987;56:254-7.

17- Robertson WD, Melfi RC. Pulpal response to vital bleaching procedures. J Endod. 1980;6:645-9.

18- Rotstein I, Dankner E, Goldman A, Heling I, Stabholz A, Zalkind M. Histochemical analysis of dental hard tissues following bleaching. J Endod. 1996;22:23-6

19- Seale NS, McIntoch JE, Taylor AN. Pulpal reaction to bleaching of teeth in dogs. J Dent Res. 1981;60:948-53.

20- Sulieman M, Addy M, Rees JS. Surface and intra-pulpal temperature rises during tooth bleaching: an in vitro study. Br Dent J. 2005;199:3740 .

21- Uysal T, Basciftci F, Usumez S, Sarý Z, Büyükerkmen A. Can previously bleached teeth be bonded safely? Am J Orthod Dentofacial Orthop. 2003;123:628-32.

22- Vandewalle KS, Roberts HW, Tiba A, Charlton DG. Thermal emission and curing efficiency of LED and halogen curing lights. Oper Dent. 2005;30:257-64.

23- White JM, Fagan MC, Goodis HE. Intra-pulpal temperatures during pulsed Nd:YAG laser treatment of dentin: in vitro. J Periodontol. $1994: 65 \cdot 255-9$

24- Wilder-Smith P, Arrastia AM, Schell MJ, Liaw LH, Grill G, Berns MW. Effect of ND:YAG laser irradiation and root planing on the root surface: structural and thermal effects. J Periodontol. 1995;66:1032-9.

25- Zach L, Cohen G. Pulp response to externally applied heat. Oral Surg Oral Med Oral Pathol. 1965;19:515-30.

26- Zalkind M, Arwaz JR, Goldman A, Rotstein I. Surface morphology changes in human enamel, dentin and cementum following bleaching: a scanning electron microscopy study. Endod Dent Traumatol. 1996;12:828 .

27-Zezell DM, Cecchini SM, Pinotti M, Eduardo CP. Temperature changes under Ho:YLF irradiation. In: Wigdor HA, Featherstone JD, White JM, Neev J, editors. Lasers in Dentistry II: Proceedings of the International Symposium on Biomedical Optics; 1996. Bellingham: SPIE; 1996. p. 34-9. 